\title{
The Value of Using Unofficial Measurements of Rainfall: The Dublin Storm and Flood of June 1963
}

\author{
Colin Clark \\ CHRS Shute Lane, Bruton, UK \\ Email: colin4chrs@hotmail.com
}

How to cite this paper: Clark, C. (2019). The Value of Using Unofficial Measurements of Rainfall: The Dublin Storm and Flood of June 1963. Journal of Geoscience and Environment Protection, 7, 76-91. https://doi.org/10.4236/gep.2019.72006

Received: January 21, 2019

Accepted: February 19, 2019

Published: February 22, 2019

Copyright $\odot 2019$ by author(s) and Scientific Research Publishing Inc. This work is licensed under the Creative Commons Attribution International License (CC BY 4.0).

http://creativecommons.org/licenses/by/4.0/

\begin{abstract}
Rainfall measurements are vital for the design of hydraulic structures, climate change studies, irrigation and land drainage works. The most important source of design rainfall data comes from convective storms. Accurate assessment of the storm rainfall requires a fairly dense network of raingauges. In 1963, such a storm took place over Dublin in Ireland. However, the existing raingauge network was insufficient to identify both the depth and pattern of rainfall. An appeal was made by Met Eireann for additional unofficial rainfall data. The result was remarkable in that the estimated maximum rainfall depth was found to be more than double the official value and that the resulting depth area analysis suggested a rainfall volume over a large area much bigger than the original isohyet map indicated. This result has huge implications for the estimation of maximum rainfall and dam safety assessment, especially in countries where the raingauge network has a low density. This paper first provides a description of the synoptic conditions that led to the storm, second an analysis of the rainfall data and how the unofficial measurements produced a very different depth area relationship; third, the social consequences of the resulting flood are described. Fourth, the storm is then placed in the context of other storms in the British Isles Finally the implications for rainfall measurement, gauge density and an example of how revised estimates of probable maximum precipitation (PMP) have been used to improve the safety and design standard of a flood detention dam are discussed.
\end{abstract}

\section{Keywords}

Raingauge Network, Unofficial Data, Maximum Rainfall Estimation, Dam Safety

\section{Introduction}

"Raingauges are the gold standard of precipitation measurement". (Strangeways, 
2007). With rainfall being measured for over 100 years in many countries, it was with some dismay that the author read that the global network is in serious decline (Sun et al., 2018). The value of measurements of rainfall to science and society has been admirably described by Hou et al. (2014), and is not repeated here. On a national scale, the UK has one of the densest networks in the world but "if the 3000 or so rain gauges were placed side by side they would cover an area less than the size of a football field" (Clark, 2002). Therefore the highest falls during a major storm, especially over hilly ground where there are fewer gauges per unit area, will almost certainly be missed. This was shown for the Martinstown UK storm in 1955 where the unofficial highest measurement was $76 \mathrm{~mm}$ higher than the official measurement (Clark, 2005). This raises serious questions about reliable long term monitoring of rainfall trends (New et al., 2001; Kidd and Huffman, 2011), flow modelling, (Andiego et al., 2018) flood warning, (Shaw, 1994), water resources, (Singh, 2017) and PMP estimation (Clark, 2002; Rakhecha \& Clark, 1999). Although there is an urgent need to have nationally recognised estimates of PMP (Faulkner \& Benn, 2016) which are reliable (Afzali-Gorouh et al., 2018) neither of these reports stressed the need for more detailed rainfall data. Some allowance for a sparse network of gauges in India where there is an average of one gauge per $913 \mathrm{~km}^{2}$ was made by Rakhecha \& Clark (1999) by applying depth area analysis. The results were extended down to an area of $10 \mathrm{~km}^{2}$ and were then maximised using WMO methods (WMO 2009). Around Mumbai, the estimates of one-day PMP were 60\% higher than the standard values in the IITM atlas (IITM, 1989), that is to say $120 \mathrm{~cm}$ instead of 70 $\mathrm{cm}$. A record breaking storm of $94 \mathrm{~cm}$ in 2005 in Mumbai proved that the lower value was in serious error, although the revised value of $120 \mathrm{~cm}$ is yet to be attained. However, the higher values are being used for dam safety assessments in Gujarat, India where the probable maximum flood (PMF) has to be estimated. As an example of the value of unofficial raingauges in rainfall studies and PMP estimation, the Dublin storm of June 1963 is analysed in this paper. The synoptic situation is then followed by an analysis of the official and unofficial rainfall measurements. A brief description of the resulting flood is given and the storm placed in the context of other storms in the British Isles. Finally, the implications for rainfall measurement in the future and estimates of PMP and PMF, with an actual example of a flood detention dam, are described.

\section{The Synoptic Situation}

At 0600 hrs on the $11^{\text {th }}$ June nearly the whole of the British Isles was under the influence of a col, Figure 1, with high pressure to the north and south and low to the east and west. McIntosh (1963) and Bonacina (1974) state that this is conducive to summer thunderstorms, and the forecast for Great Britain and Northern Ireland mentioned isolated thunder breaking out in some western districts. About $320 \mathrm{~km}$ to the west of Ireland an occluded front aligned NW-SE and then NNW-ESE as it moved eastwards. Conditions were overcast in W Ireland but 


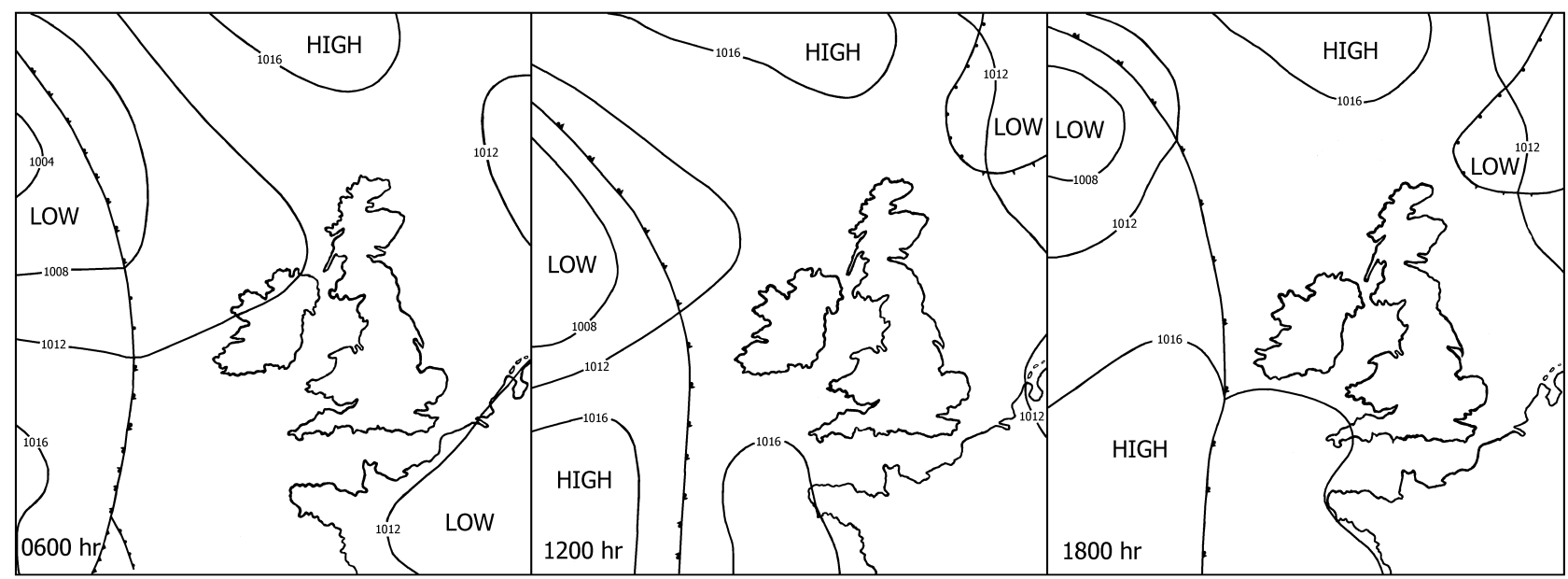

Figure 1. Simplified synoptic charts for 11 June 1963.

rather more clear in the east. At Roches Point thunder was heard and continued for another hour. During the next 6 hours the occluded front moved $80 \mathrm{~km}$ eastwards and at the same time pressure rose from $1012.6 \mathrm{hPa}$ to $1013.5 \mathrm{hPa}$ at Dublin Figure 2. At the same time the dewpoint temperature-a good indicator of atmospheric moisture-reached $16 \mathrm{deg}$ C, with air temperature $3 \mathrm{deg} \mathrm{C}$ warmer. Rain was now falling over the Dublin area and by $1800 \mathrm{hr}$ the front had almost reached the SW Irish coast. Thunderstorms were reported at Aldergrove in Northern Ireland, Malin Head in Donegal, and Collinstown about $5 \mathrm{~km}$ east of Ballsbridge in Dublin. During the thunderstorm pressure dropped by just 1 $\mathrm{hPa}$, so the storm was largely driven by convection.

The upper air charts, Figure 3 confirm both the presence of the col into the middle troposphere and a warm pool of air over western Europe and the south west approaches. Light winds such as $4 \mathrm{kts}$ at Collinstown just to the west of Dublin complete the synoptic situation.

\section{Distribution of Rainfall}

The official maximum rainfall for the day was $98 \mathrm{~mm}$ at Ballsbridge, Dublin, Figure 4, which shows the distribution of rainfall using the official raingauge data and then augmented by the unofficial data. Figure 5 shows the location of most of the places mentioned in the text. The depth duration of the storm is shown by the autographic record at Ballsbridge and also by unofficial manual measurements made at Mount Merrion between 1350 hrs and 1450 hrs of 46 $\mathrm{mm}$ and $77 \mathrm{~mm}$ respectively. However, the highest unofficial fall was $235 \mathrm{~mm}$ at Churchtown and the implied depth duration relations of this and the Ballsbridge site are shown in Figure 6.

Morgan (1971) gives a list of 24 official gauges at which $+10 \mathrm{~mm}$ were recorded. Because of the scale of the flood damage an appeal was made to the public for more information. The result was remarkable. Table 1 shows the outcome.

In an account of the accuracy of these measurements Morgan (1971) debated 


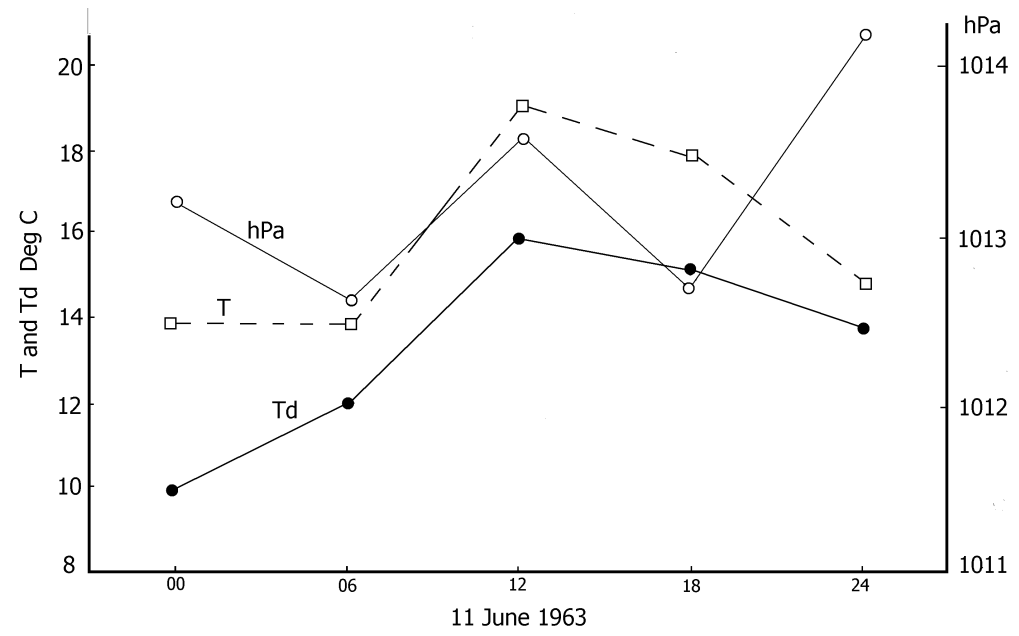

Figure 2. Changes in air pressure, temperature and dew point at Collinstown 11 June 1963.

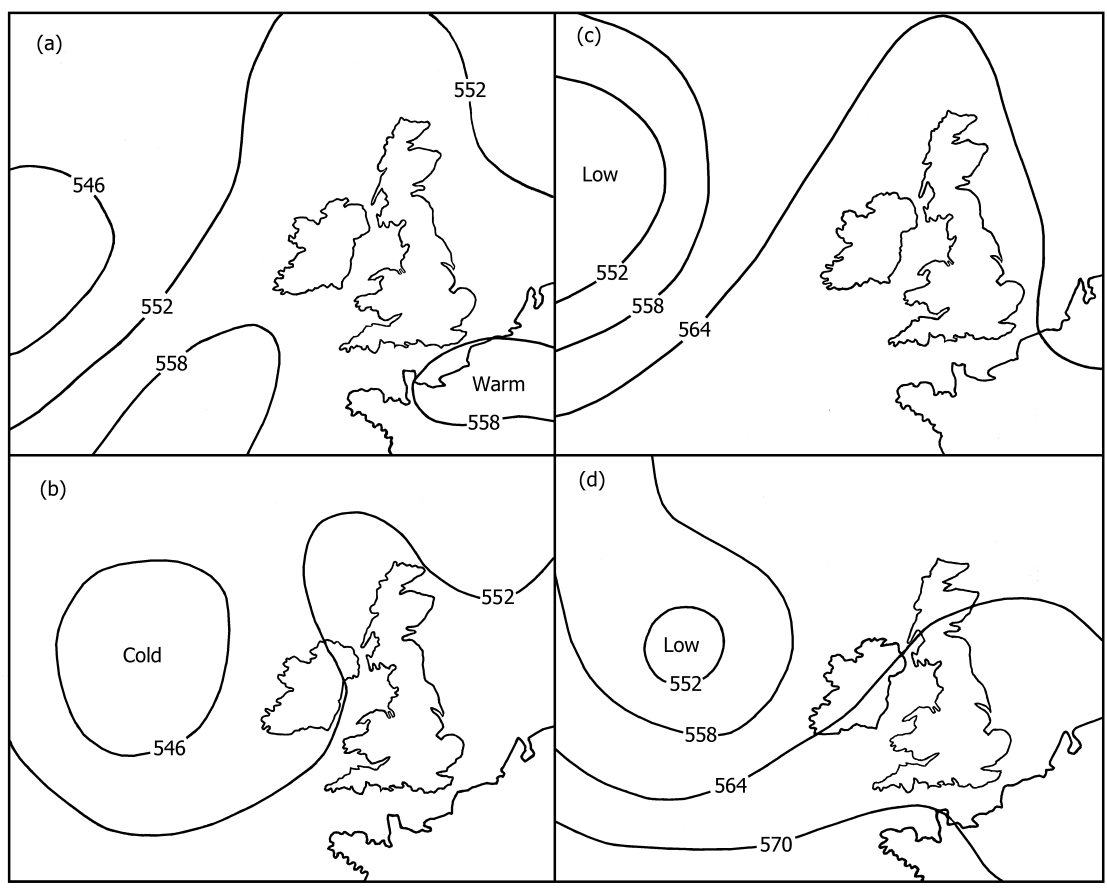

Figure 3. (a) and (b) Contours of the $1000-500 \mathrm{hPa}$ thickness charts for $0000 \mathrm{hr} 11$ and 12 June 1963. (c) and (d) Contours of the $500 \mathrm{hPa}$ surface $0000 \mathrm{hr} 11$ and 12 June 1963.

Table 1. Unofficial rainfall measurements.

\begin{tabular}{ccc}
\hline Location & Depth $(\mathrm{mm})$ & Method of measurement \\
\hline Churchtown & 235 & A can $203 \mathrm{~mm}$ diameter and $289 \mathrm{~mm}$ high \\
Mount Merrion & 184 & Raingauge \\
Blackrock & 150 & Bucket \\
Mount Merrion (2) & 142 & Glass tank $305 \mathrm{~mm} \times 219 \mathrm{~mm}$ and $454 \mathrm{~mm}$ high \\
Donnybrook & 131 & Bucket well exposed \\
Sandymount & 91 & Bucket \\
Clontarf & 54 & Raingauge \\
\hline
\end{tabular}




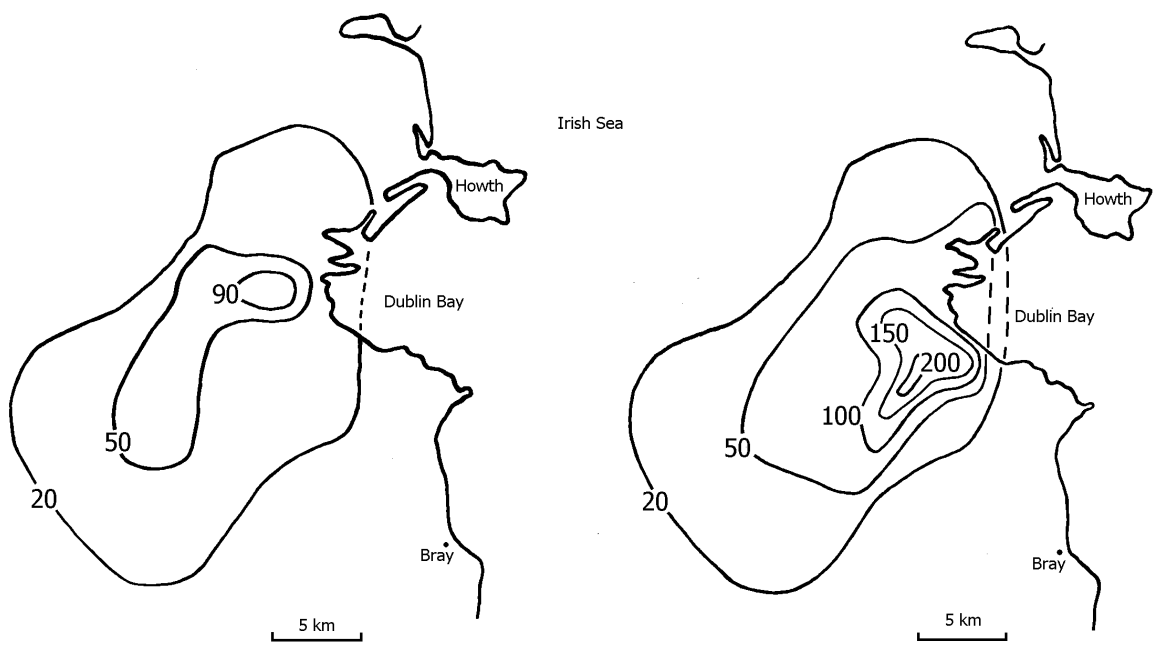

Figure 4. Distribution of storm rainfall using official and with the addition of unofficial measurements.

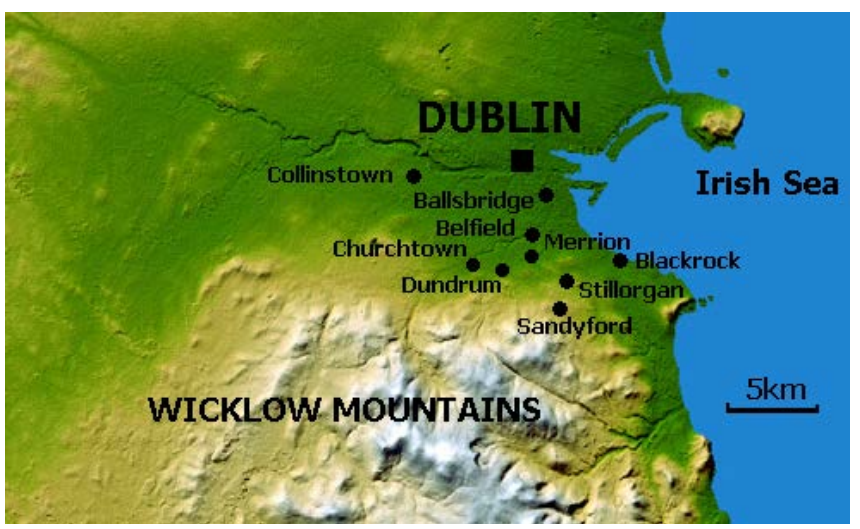

Figure 5. Location of some places mentioned in the text.

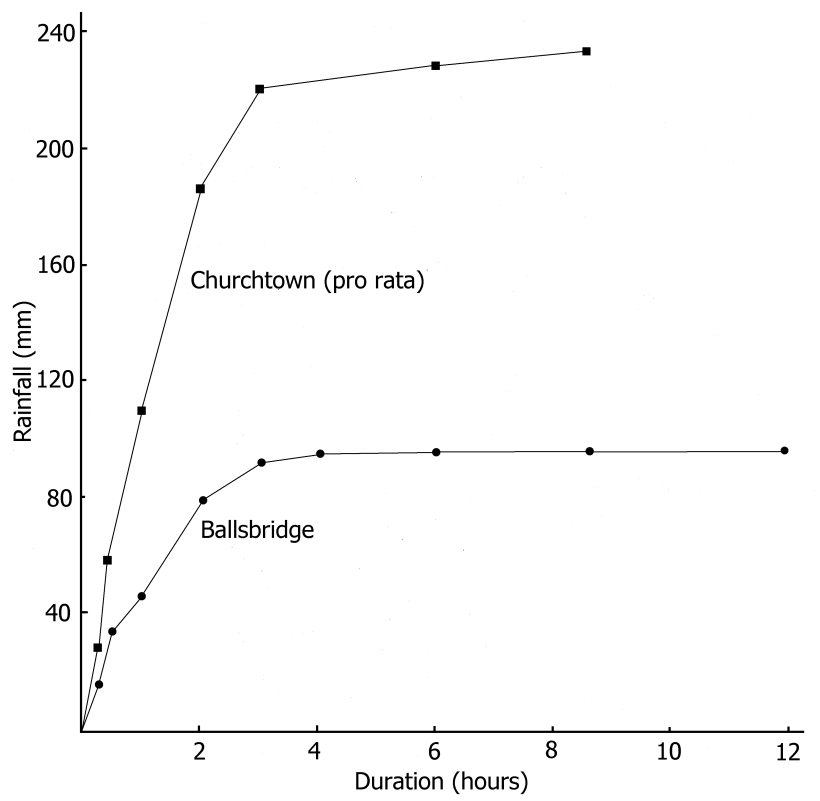

Figure 6. Depth duration of the storm at Ballsbridge and Churchtown. 
the poor siting of the Churchtown site in terms of both insplashing and outsplashing. However, Clark (2016) showed that a bucket gauge sited $2.5 \mathrm{~m}$ from a two storey house and closer to a nearby bush in the southerly direction than twice its height, gave very satisfactory results, Figure 7 . This being the case there is no overriding reason to reject the value of $235 \mathrm{~mm}$ especially as it is backed up by a raingauge reading of $184 \mathrm{~mm}$ and unlikely to have caught the highest rainfall.

Comparing the two isohyet maps, Figure 4 shows how the unofficial readings have produced a remarkable transformation of the distribution of storm rainfall. The storm is much more concentrated and the centre is shifted about $4 \mathrm{~km}$ south of Ballsbridge Showground. The effect of the extra data extends to the 50 $\mathrm{mm}$ isohyet SSW of Merrion.

The great contrast between the official and unofficial rainfall measurements is also shown by depth area analysis Figure 8 . There is no method known to the author that could have predicted the augmented depth area curve by only using the official measurements.

\section{The Flood}

The effects of such a concentrated storm were exceptional and are best described by newspaper reports. The Irish Times (12/6/1963) stated: "Early today, householders in Stillorgan, Blackrock, Mount Merrion, Dundram, Sandyford and Merrion were trying to restore some kind of order following the destruction caused in their homes by the retreating waters, even then still lapping around their feet ... during the height of the storm thousands of workers were leaving the city for home. One man was thrown high into the air in Pearse Street as a blast of lightning hit the footpath where he walked He was treated for burns in Sir Patrick Dun's Hospital. The concentration of the flooding in the Merrion

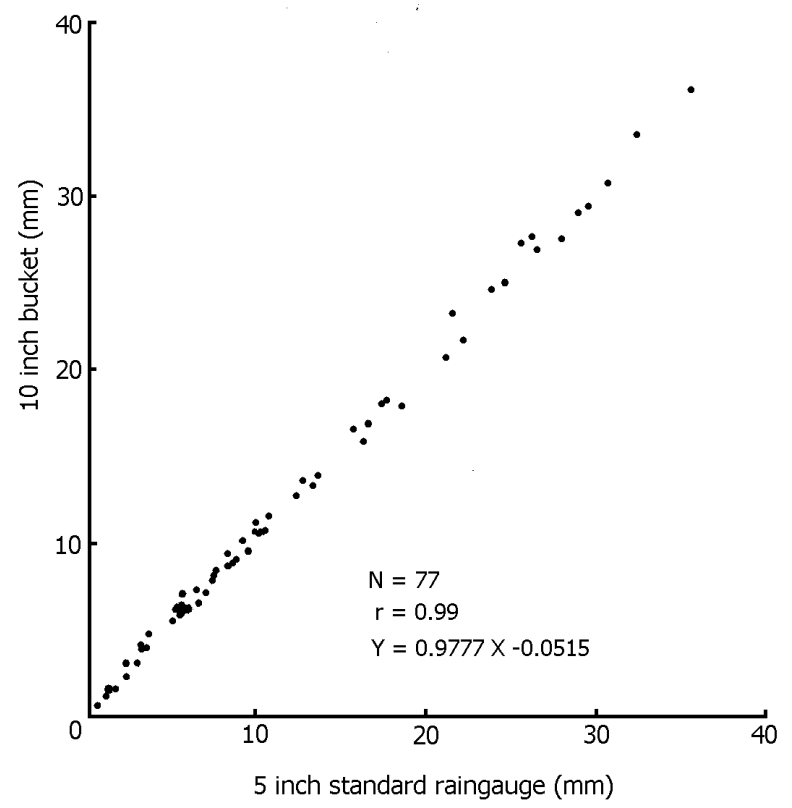

Figure 7. Comparison of standard and bucket raingauge observations (Clark, 2016). 


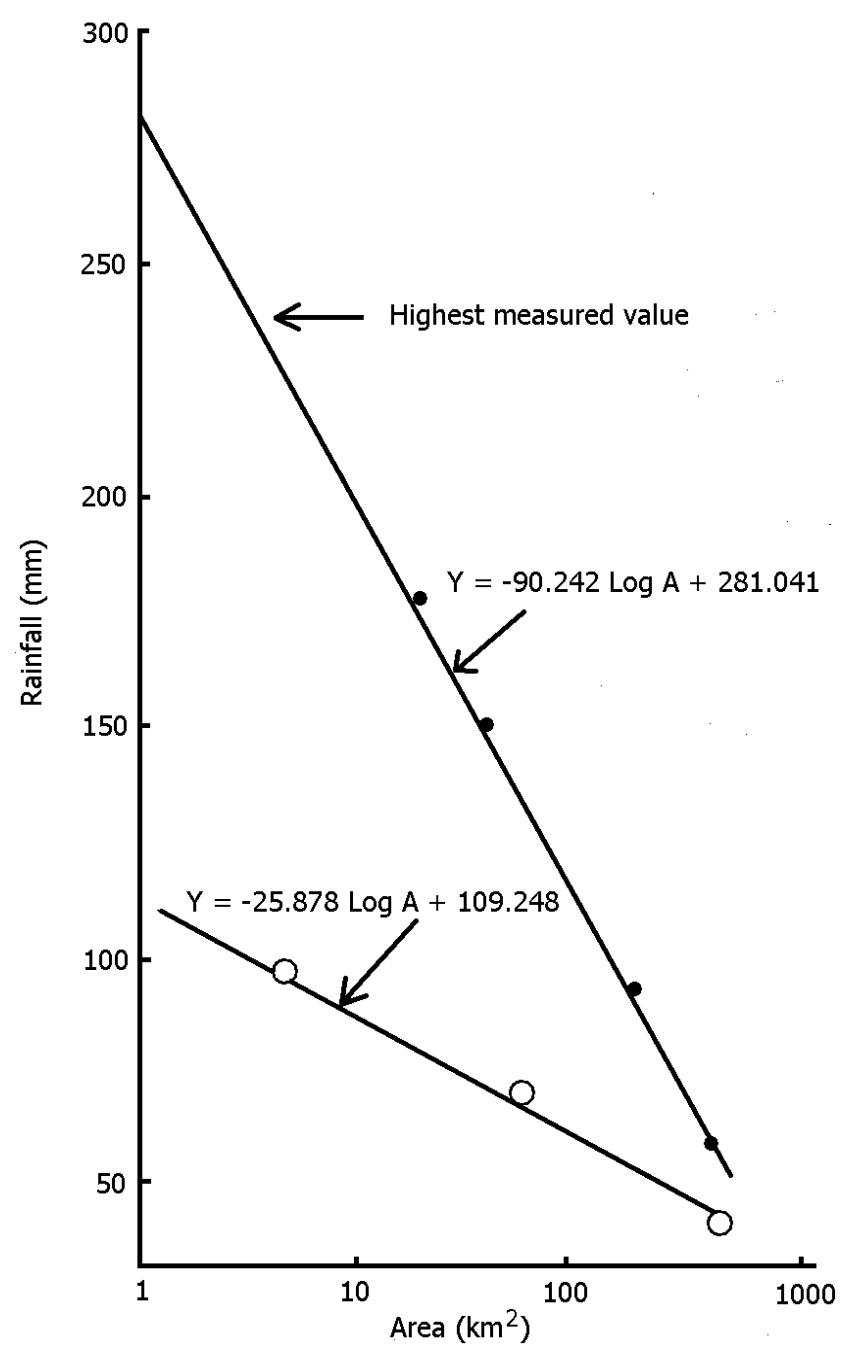

Figure 8. Depth area analysis of the storm Open circles official data. Closed circles with unofficial data.

area is believed to be due to lightning which wrecked the automatic pumping station... this normally keeps the low-lying lands at Merrion free of floods". The Irish Independent (12/6/19063) continues: "An artificial night fell over Dublin at the height of the storm at $3 \mathrm{pm}$ with lightning flashes streaking eerily through the gloom. Motorists drove with headlights on... Torrents cascaded in and out of houses and in some cases bore furniture out through windows. Fire Brigade, Gardai, Civil Defence and Corporation workers, aided by clergy and civilians, were still battling late last night. Two children on their way from school at Goatstown were rescued after being swept some distance by a fast moving torrent on the main Goatstown Road... Dr Joseph McNeaney in Lower Kilmacud Road had to take refuge with his family in the upstairs rooms of his home when water flooded the ground floor to a depth of five feet when a small river at the rear of the house overflowed." Similarly, as reported in the Irish Times 12/6/1963: "Two gardens in Grove Avenue were completely under water as the stream in the area flooded". 
The Evening Press (12/6/1963) reported Miss Coleman of Allesbury Park as saying "I got home by taxi at $4 \mathrm{pm}$, yesterday and found the water up to the steps. Shortly after, it burst in through the kitchen which became flooded ... about $8 \mathrm{pm}$ the water rushed into the hall and flooded all the downstairs rooms. The average depth of the water in St Albans Park was 3 1/2 feet". Lorry drivers did their best to drive through the waters but: "three hours later a lorry driver ignoring the advice of many motorists drove into the swirling waters only to be bogged down in the deepest part. He had an attractive girl companion in the cab. When the vehicle showed no signs of extricating itself he clambered out to the back and jumped into the water which was waist high. From there he gallantly carried his girl friend to dry land" (Irish Times 12/6/1963). The following day at Ballsbridge people were seen using boats to get about Figure 9 with Miss Griffin and Stanley Paisley paddling along in the front boat.

From these descriptions it is clear that both fluvial and surface water caused the damage. With low land gradients the water was slow to subside, while the pumping station failure made the situation worse.

\section{The Storm in the Context of UK Extreme Storms}

The Dublin storm must be placed in relation to other extreme storm events since this gives a better description on a Nationwide scale. There are several examples of depth duration data (Rodda, 1970; Austin et al., 1995; Clark, 1995). Figure 10 shows the results of this approach which includes the Dublin storm. The estimated duration of 9 hours is based on the 1000 - 1900 hrs GMT collection period at Churchtown. While Ireland is a separate land mass to Britain, it covers the same latitudes so that comparable rainfall depths would be expected. The key finding from Figure 10 is that without maximisation of storm depths (WMO, 2009) the expected $24 \mathrm{hr}$ rainfall is about $400 \mathrm{~mm}$. This is in excess of the 300 mm given in the Flood Studies Report (NERC, 1975). In view of this the technique of storm maximisation was applied. The maximum persisting dewpoints

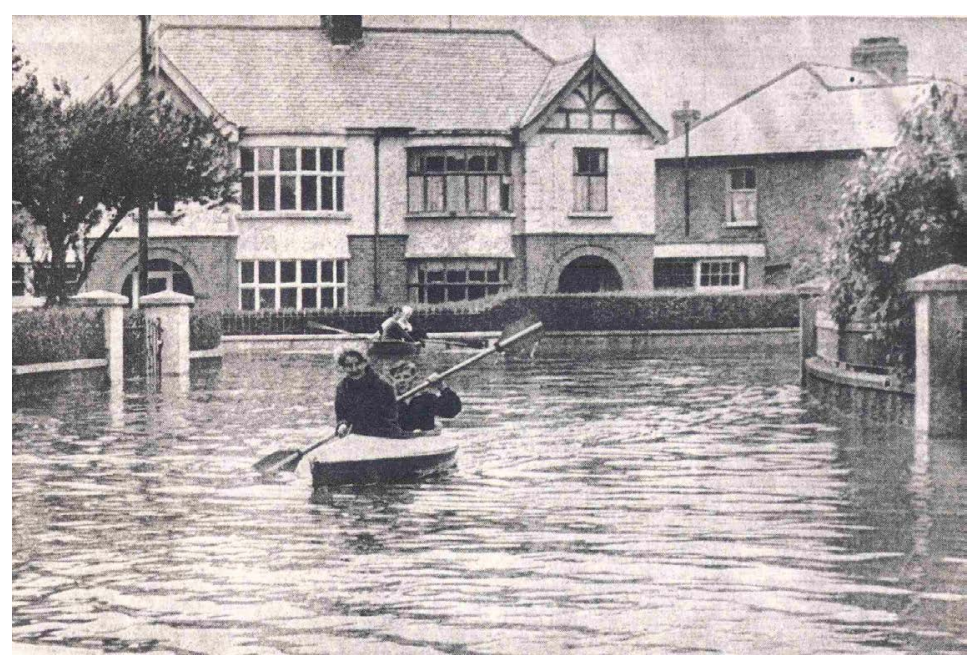

Figure 9. Residents going about their business by boat 11 June (Evening Post 12/6/1963). 


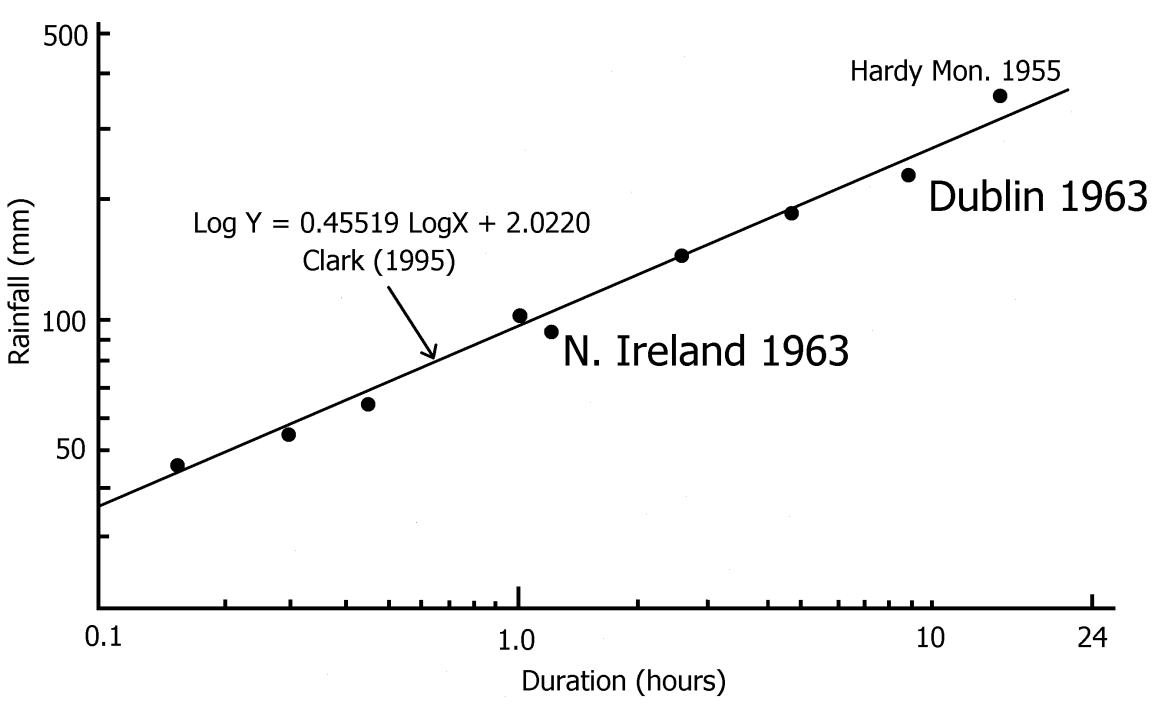

Figure 10. Depth duration of rare storms in SW England and Ireland 11 June 1963.

for Collinstown were gathered from the Daily Weather Reports and subjected to an extreme frequency analysis. Figure 11 shows the results. During many, but not all storms, the highest persisting dewpoint for that time of year is not reached. The WMO manuals for estimating probable maximum precipitation (PMP) have consistently advocated comparing the maximum dewpoint of the storm with the 100-year persisting dewpoint for the same time of year. This is defined as a time period 15 days either side of the storm date. Figure 2 shows that the $12 \mathrm{hr}$ persisting dewpoint was $12 \mathrm{deg} \mathrm{C}$, while Figure 11 shows the 100-year persisting dewpoint is $17 \mathrm{deg} \mathrm{C}$. Air masses with these temperatures will hold different depth of moisture, called precipitable water (PW) and the WMO manual has a table that relates $\mathrm{PW}$ to temperature. This depth will be less than the storm rainfall because air is continually fed into the storm cell over the period of interest. The ratio of the maximum $\mathrm{PW}$ to the storm $\mathrm{PW}$ gives the moisture maximisation factor. When multiplied by the observed rainfall gives an estimate of what the rainfall would have been under the most extreme conditions:

$$
M_{R}=R \times \mathrm{PW}_{\max } / \mathrm{PW}_{\text {storm }}
$$

In the present case this becomes $=235 \times 40.5 / 25.9=367 \mathrm{~mm}$. However, from Figure 2 the storm period did not start until about $0900 \mathrm{hr}$ when the dewpoint was $14 \mathrm{deg}$ C. thus the maximised rainfall $=334 \mathrm{~mm}$. Assuming that the depth duration relationship has the same rate of change over the range 1 - 24 hours this equates to a $24 \mathrm{hr}$ PMP of about $500 \mathrm{~mm}$. This is similar to that obtained for parts of SW England (Clark, 1995) and Britain (Clark, 2002), with the latter study using WMO methods with storm transposition where the storm is physically moved and the maximisation process repeated according to PW characteristics and altitude in a meteorologically homogenous area. This analysis was further backed up by standard frequency analysis. 
Return period (years)

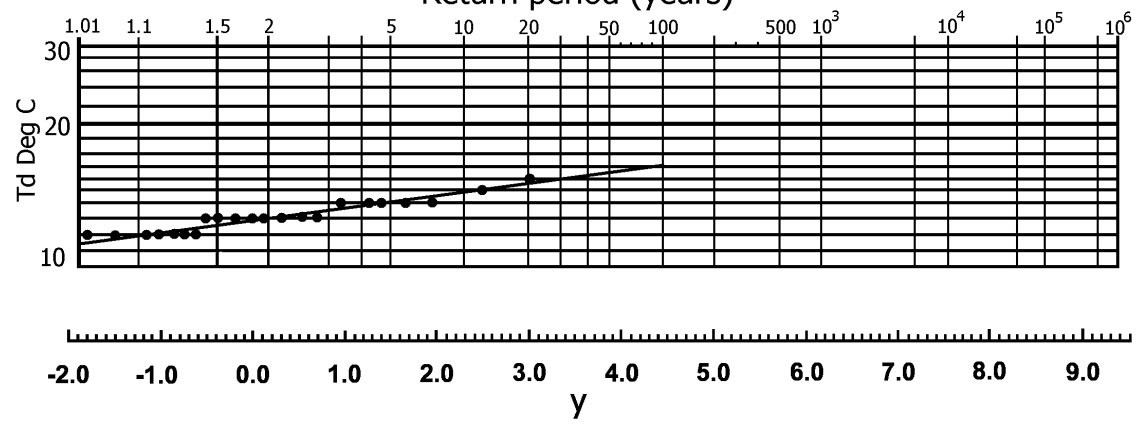

Figure 11. Frequency analysis of $12 \mathrm{hr}$ maximum persisting dewpoint at Collinstown.

\section{Implications for Raingauge Networks, Radar Rainfall, PMP and Dam Safety}

Over 80 years ago the Institution of Water Engineers, IWE (1937) produced guidelines for the minimum number of raingauges for reservoired catchments. Their recommendations are shown graphically in Figure 12 together with an estimate by Bleasdale (1965). Referring to the Dublin storm (Figure 2) the density of the official network meets the IWE standard but this was much less dense in the central area of the storm than when the unofficial measurements are included. Results from the Martinstown storm (Clark, 2005) are also included. Some 40 years later IOH (1977) suggested network densities for soil moisture deficit, agriculture, and flood design, making the point that "the most stringent requirements are met nowhere in the existing network apart from in local clusters". This is made clearer in Table 2 which also shows how the situation has improved in Ireland while in Britain it has worsened.

During the past 30 years increasing resort has been made to radar rainfall which can be calibrated with telemetered rainfall measurements. However, the accuracy will depend on the correct density of raingauges in the first place. Radar rainfall tends to be less accurate for higher rainfall, and by implication higher intensity, (Sebastianelli et al. 2013; Espinosa et al., 2015). When radar based rainfall are used to produce a flood frequency curve via input into a hydrological model (Wright et al., 2014) for a $31 \mathrm{~km}^{2}$ sub-tropical catchment in North Dakota gave a 1 in 1000 year flood estimate of only 200 cumecs, which is just above that for the Upper Brue in the UK which has a temperate climate. There were no historic flood data that were used to help validate their result.

A key concern for the future is the maintenance and improvement of the raingauge network, especially in countries with a low network density. Following the opening remarks by Strangeways (2007) a National appeal should be made to encourage more people to measure rainfall, a practice that was largely the province of the public as volunteers, pioneered by George Symons during the 1850's. Quality control can be achieved through published guidelines made freely available. The standard raingauge measuring funnel can be replaced by a simple weighing machine and conversion factor. This would save time during a major 


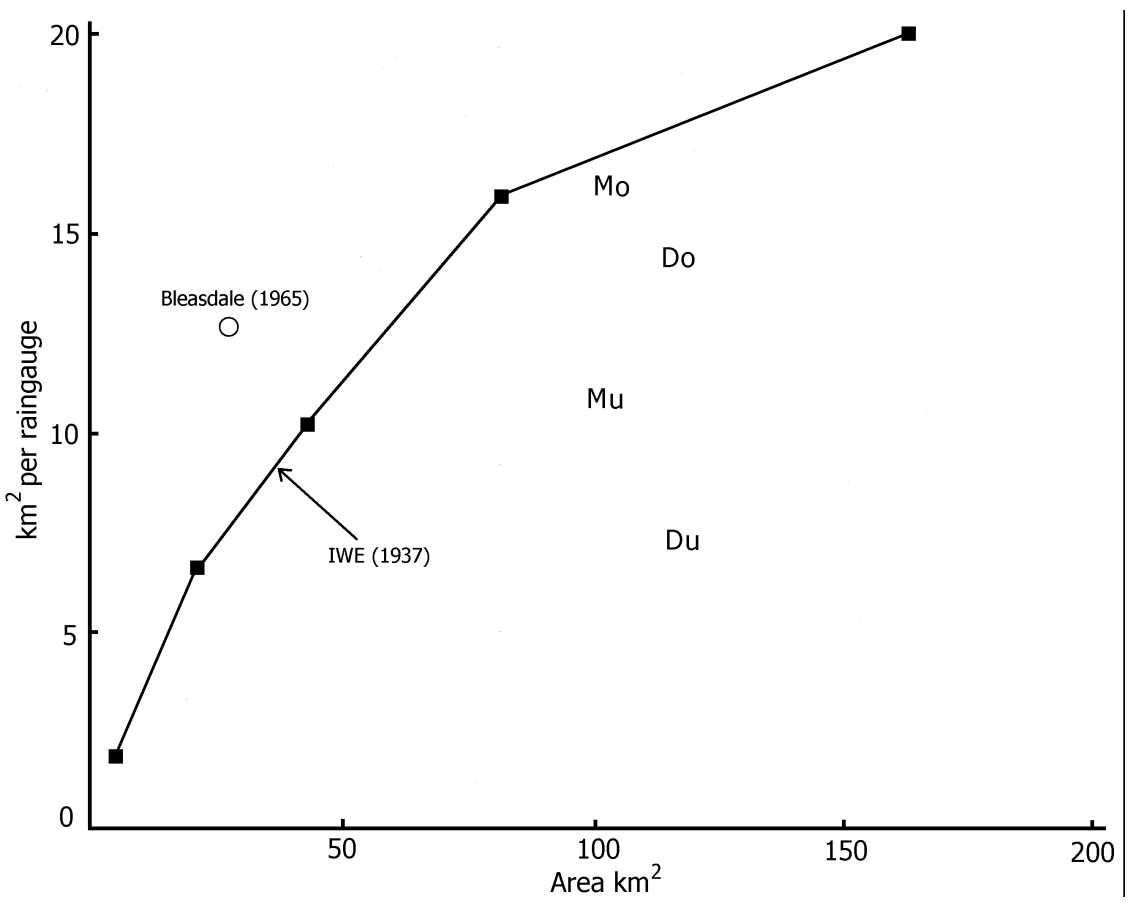

Figure 12. Institute of Water Engineers' standard of raingauge density. Mo = Martinstown storm official. $\mathrm{Mu}=$ Martinstown unofficial. $\mathrm{Do}=$ Dublin official. $\mathrm{Du}=$ Dublin unofficial.

Table 2. Comparison of daily raingauge networks in 1935 and 2007.

\begin{tabular}{ccccc}
\hline \multicolumn{3}{c}{1935} & \multicolumn{2}{c}{2007} \\
\hline & Number of gauges & $\left(\mathrm{km}^{2}\right.$ per gauge $)$ & Number of gauges & $\left(\mathrm{km}^{2}\right.$ per gauge $)$ \\
\hline Irish Republic & 189 & 371.9 & 474 & 148.5 \\
N. Ireland & 68 & 207.8 & 103 & 137.2 \\
Britain & 3790 & 60.9 & 2665 & 86.6 \\
\hline
\end{tabular}

storm if the bucket began to fill up, with a danger of outsplashing taking place. As has been shown above, a simple bucket can give sensible measurements of rainfall.

Given that $24 \mathrm{hr}$ PMP in the Dublin area has been assessed as about $500 \mathrm{~mm}$, a result very comparable with Britain, it is likely that design rainfall depth will also be higher than the Flood Studies Report (NERC, 1975). Higher $2 \mathrm{hr}$ and 24 hr PMP was necessary to reproduce the historic flood record and estimated probable maximum flood for the upper Brue, Somerset UK. This was used by consultants Black \& Veatch (2006) in an assessment of the spillway design flood for the Bruton dam on the upper Brue. The original value was 240 cumecs, but using the higher rainfall estimates, combined with higher percentage runoff and lower time to peak of the flood hydrograph, a value in excess of 500 cumecs was produced (Black \& Veatch, 2006) almost the same as Clark (1997). This led to major improvement works on the Bruton dam (Pether, 2010). However, general advice on the use of higher estimates of both design rainfall and PMP has not 
been issued. Design rainfall estimates are based on probability theory, whereas PMP estimates are deterministic. On the face of it the two parameters cannot be combined into a unified frequency analysis. However, several attempts have been made to give PMP a probability (Lowing \& Law, 1995; Austin et al., 1995; Koutsoyiannis, 2007; Fontaine \& Potter, 1989; Nathan et al., 2016). The overall consensus is that the annual exceedance probability (AEP) of PMP is somewhere between 250,000 - 2 million years. Given that there is no correct value for the AEP it is instructive to calculate the effect of the range of estimates-always assuming that they are realistic-on for example the 1 in 100 year rainfall. The results for $24 \mathrm{hr}$ rainfall at the Bruton dam site are shown in Table 3. Two frequency distributions are tested, the modified Gumbel scale (Rakhecha \& Clark, 1999) hereafter RC, and the Gumbel scale (Gumbel, 1958).

The range of estimates for both the 1 in 100 and 1 in 1000 year rainfall is much bigger when using the Gumbel scale. What is more alarming is that the estimates using the RC scale are much bigger. The largest difference is a factor of 1.75 for 1 in 1000 year rainfall with an AEP $=2 \times 10^{6}$ years. The small range of values using the RC scale are well within an uncertainty band of $20 \%$ for this type of analysis with a difference of $6 \%$ for the 1 in 100 year rainfall depth between the highest two exceedance probabilities. This contrasts with a difference of $10 \%$ using the Gumbel scale. The RC 1 in 1000 year estimates are $46 \%$ higher than the Gumbel based estimate. So which estimates are the more realistic? Fortunately for the East Somerset area in the first instance there is a 292 year historic flood record for the upper Brue at Bruton (Clark, 2014) and rainfall records (Clark \& Pike, 2007) that are detailed enough to allow a test of the two frequency scales. On June 281917 Bruton had the second highest flood in the historic record. From the daily rainfall record the soil moisture deficit prior to the storm was about $64 \mathrm{~mm}$. The estimated storm profile based on manual measurements made at Bruton gives an effective rainfall of $107 \mathrm{~mm}$ in about 7.6 hours. The FEH CDROM areal 2-year $7.6 \mathrm{hr}$ rainfall $=25.5 \mathrm{~mm}$. Using 1-hr and $24 \mathrm{hr}$ PMP estimates (Clark, 2002) the 7.6 hour point PMP $=376 \mathrm{~mm}$ which when reduced by the areal reduction factor (Clark, 2012) for a catchment area of $31 \mathrm{~km}^{2}=256 \mathrm{~mm}$. The Gumbel equation for the reduced variate: $-\ln (1-1 / T)$ where $T=$ return period (years). Taking a value of the AEP $=10^{6}$ years gives a value of the reduced variate $=13.8155$. The modified reduced variate, $\mathrm{RC}$ gives a value for the reduced variate $=9.3826$. The resulting rainfall frequency equations are:

Table 3. Rainfall estimates based on different estimates of the AEP of PMP.

\begin{tabular}{ccccc}
\hline & \multicolumn{2}{c}{24 hr rainfall $(\mathrm{mm})$ RC } & \multicolumn{2}{c}{24 hr rainfall Gumbel } \\
\hline AEP of PMP & 1 in 100 year & 1 in 1000 year & 1 in 100 year & 1 in 1000 year \\
\hline $4 \times 10^{-6}$ & 138 & 226 & 98 & 158 \\
$10^{-6}$ & 130 & 208 & 89 & 137 \\
$2 \times 10^{-6}$ & 127 & 201 & 79 & 115 \\
\hline
\end{tabular}




$$
\begin{gathered}
\log R=0.1089 y+1.3859(\mathrm{RC}) \\
\log R=0.0744 y+1.3792 \text { (Gumbel) }
\end{gathered}
$$

These equations give return periods of 745 years and 6180 years respectively for the effective storm rainfall. Since the rarity of the threshold SMD (Clark, 2018) $=4.07$ years, a value based on evaporation measurements at CHRS and a corrected 142 year rainfall record, then the estimated return period of the flood can be calculated (Clark, 2012, 2018):

$$
R p_{\text {FLOOD }}=R p_{\text {ER }} \times R p_{\text {SMD }}
$$

where $\mathrm{ER}=$ effective rainfall $=$ rainfall $-\mathrm{SMD}$ down to the threshold SMD. This gives return periods of the flood event as 3030 years (RC) and 25,150 years (Gumbel). The historic flood frequency analysis (Clark, 2014) shows that the 1917 flood had a return period of 1930 years. To obtain a rarity of 1 in 25,150 years would mean a peak discharge of 246 cumecs, which is 70 cumecs higher than the estimated value of 175 cumecs. A discharge of 193 cumecs has a rarity of 3030 years These differences show that the Gumbel scale produces unrealistic estimates of both rarity and design rainfall depth. If on the other hand the Gumbel derived rarity was correct then the 1979 flood on the Brue would need a channel roughness value of 0.042 which is excessively high and it would also mean a probable maximum flood (PMF) of 260 cumecs which has a runoff rate considerably below the Extreme Catastrophic Flood of Allard, Glassspole, \& Wolf (1960).

In a worldwide study of rainfall Papalexiou \& Koutsoyiannis (2013) have also shown that the Gumbel scale is not suitable for analysing extreme rainfall. The argument has been extended (Koutsoyiannis \& Papalexiou, 2017) which showed that the Gumbel distribution gave lower design rainfall estimates than the Frechet distribution. Further details of this important result, which is supported by the present analysis are given in Papalexiou et al. (2013).

\section{Conclusion}

The initiative of Met Eireann to enquire if local people had any records of the storm of June 111963 has proven to be of great value. It also highlights the need for more registered raingauges, especially in upland areas where the density of gauges is low and, more important, where many reservoirs are located.

The most important role of science is to provide an accurate description of nature. The humble raingauge which was pioneered on a systematic basis by Richard Townley during the $17^{\text {th }}$ century and later developed on a National scale by George Symons, remains the best way of providing a description of rainfall. But in recent years it has become neglected, fallen out of fashion, as the reliance on indirect methods has grown. This may be a mistake as shown in retrospect by the Dublin storm. The estimated $24 \mathrm{hr}$ PMP for the Dublin area is about $500 \mathrm{~mm}$ which is $200 \mathrm{~mm}$ in excess of the value given in the FSR (NERC, 1975). This has serious implications for dam safety. Similarly, higher values of PMP were used to justify the improvement of the Bruton dam. Furthermore, higher estimates of 
PMP in India were obtained by using depth area analysis (RC), which overcomes to a certain extent the rather sparse raingauge network of one gauge per 913 $\mathrm{km}^{2}$. To begin with the higher values were disbelieved until the storm of July 2005 over Mumbai when existing estimates of PMP were exceeded by $24 \mathrm{~cm}$ ! The much higher PMP values for India have been used in an assessment of dam safety in Gujarat. It is not clear why more general guidance has not been issued for Britain. The FEH13 (Stewart et al., 2013) omitted a consideration of PMP which is some way be linked to rainfall of a lower rarity. Higher design rainfall estimates have been produced as a result of the analysis of the Dublin storm. Estimates of PMP for the whole of Ireland are now being produced. The implications for the design of dam spillways and other drainage works are serious.

\section{Acknowledgements}

The author would like to thank staff at Met Eireann for supplying data on the Dublin storm.

\section{Conflicts of Interest}

There is no competing or conflict of interest in this study.

\section{References}

Afzali-Gorouh, Z., Bakhtiari, B., \& Qaderi, K. (2018). Probable Maximum Precipitation Estimation in a Humid Climate. Natural Hazards and Earth System Sciences, 18, 31093119. https://doi.org/10.5194/nhess-18-3109-2018

Allard, W., Glasspole, J., \& Wolf, P. O. (1960). Floods in the British Isles. Proceedings of the Institution of Civil Engineers, 15, 119-144.

Andiego, G., Waseem, M., Usman, M., \& Manti, N. (2018) The Influence of Rain Gauge Network Density on the Performance of a Hydrological Model. Computational Water, Energy, and Environmental Engineering, 7, 27-50. https://doi.org/10.4236/cweee.2018.71002

Austin, B. N., Cluckie, I. D., \& Collier, C. G. (1995). Radar-Based Estimation of Probable Maximum Precipitation and Flood. Metstar Consutlants. Bracknell. Report for DOE, $123 \mathrm{p}$.

Black \& Veatch (2006). Bruton Flood Storage Reservoir. Report on Hydraulic and Hydrological Studies. $43 \mathrm{p}$

Bleasdale, A. (1965). Rain Gauge Networks Development and Design with Special Reference to the United Kingdom. Pro. WMO/IASH Symposium on the Development of Hydrological Networks, 67, 46-54.

Bonacina, L. C. W. (1974). The Weather in Cols. Weather, 29, 158.

Clark, C. (1995). New Estimates of Probable Maximum Precipitation in South-West England. Meteorl. Appl., 2, 307-312. https://doi.org/10.1002/met.5060020403

Clark, C. (1997). Cause for Concern. International Water Power and Dam Construction, 49(4), 34-37.

Clark, C. (2002). Rainfall Estimates (PMP) in Great Britain. International Water Power and Dam Construction, 54(5), 18-26.

Clark, C. (2005). The Martinstown Storm 50 Years on. Weather, 60, 251-257. 
https://doi.org/10.1256/wea.58.05

Clark, C. (2012). Spillway Design Flood and Flood Volume Estimated Using the New Guide to Flood Estimation. In: T. S. W. Wong (Ed.), Flood Risk and Flood Management (pp. 219-255), New York: Nova Science.

Clark, C. (2014). The Great Flood of 1726 at Bruton, UK. Weather, 69, 249-253. https://doi.org/10.1002/wea.2272

Clark, C. (2016). Reply to Stephen Burt's Comments on the Scarborough Storm and Flood. Weather, 70, 280-284. https://doi.org/10.1002/wea.2512

Clark, C. (2018). The Storm and Flood of 13 May 1906 at Mells, Somerset UK. Weather, 73, 109-115. https://doi.org/10.1002/wea.3230

Clark, C., \& Pike, W. S. (2007). The Bruton Storm and Flood after 90 Years. Weather, 62, 300-305. https://doi.org/10.1002/wea.142

Espinosa, B., Hromadka, T. V., \& Perez, R. (2015). Comparison of Radar Data versus Rainfall Data. MethodsX, 2, 423-431. https://doi.org/10.1016/j.mex.2015.10.007

Faulkner, D., \& Benn, J. (2016). Reservoir Flood Estimation: Time for a Re-Think. In 19th Biennial Conference of British Dam Society (pp. 1-13). London: ICE Publishing.

Fontaine, T. A., \& Potter, K. W. (1989). Estimating Probabilities of Extreme Rainfalls. Journal of Hydraulic Engineering, 115, 1562-1575. https://doi.org/10.1061/(ASCE)0733-9429(1989)115:11(1562)

Gumbel, E. J. (1958). Statistics of Extremes (375 p.). New York: Columbia University Press.

Hou, A. Y., Kaker, R. K., Neeck, S., Azarbarzin, K., Kummeron, C. D., Kojima, M., Oki, R., Nakamura, K., \& Iguchi, T. (2014). The Global Precipitation Measurement Mission. Bulletin of the American Meteorological Society, 95, 702-722. https://doi.org/10.1175/BAMS-D-13-00164.1

Indian Institute of Tropical Meteorology IITM (1989). Probable Maximum Precipitation Atlas. Pune: IITM.

Institute of Water Engineers IWE (1937). Report of Joint Committee to Consider Methods of Determining General Rainfall over Any Area. Transactions of the Institution of Water Engineers, 42, 231-259.

$\mathrm{IOH}$ (1977). Methods of Evaluating the UK Rain-Gauge Network (262 p.). IOH Report 40, Wallingford.

Kidd, C., \& Huffman, G. (2011). Global Precipitation Measurement. Meteorological Applications, 18, 334-353. https://doi.org/10.1002/met.284

Koutsoyiannis, D. (2007). A Critical Review of Probability of Extreme Rainfall: Principles and Models (pp. 139-166). Advances in Urban Flood Management, London: Taylor and Francis.

Koutsoyiannis, D., \& Papalexiou, S. M. (2017). Extreme Rainfall: Global Perspective. In V. P. Singh (Ed.), Handbook of Applied Hydrology (pp. 74.1-74.16). New York: McGraw Hill.

Lowing, M. J., \& Law, F. M. (1995). Reconciling Flood Frequency Curves with the Probable Maximum Flood. In BHS 5th National Hydrology Symposium.

McIntosh, D. H. (1963). Meteorological Glossary(288 p). London: HMSO.

Morgan, W. A. (1971). Rainfall in the Dublin Area on $11^{\text {th }}$ June 1963 (7 p). Dublin: Met Eireann.

Nathan, R., Jordan, P., Scorah, M., Lang, S., Kuczera, G., Schaefer, M., \& Weinmann, E. (2016). Estimating the Exceedance Probability of Extreme Rainfalls up to the Probable 
Maximum Precipitation. Journal of Hydrology, 543, 706-720.

https://doi.org/10.1016/j.jhydrol.2016.10.044

NERC (1975). Flood Studies Report (5 Vols.). London: Meteorological Office.

New, M., Todd, M., Hulme, M., \& Jones, P. (2001). Precipitation Measurements and Trends in the Twentieth Century. International Journal of Climatology, 21, 1899-1922. https://doi.org/10.1002/joc.680

Papalexiou, S. M., \& Koutsoyiannis, D. (2013). Battle of Extreme Value Distributions: A Global Survey on Extreme Daily Rainfall. Water Resources Research, 49, 187-201. https://doi.org/10.1029/2012WR012557

Papalexiou, S. M., Koutsoyiannis, D., \& Makropoolo, S. C. (2013). How Extreme Is Extreme? An Assessment of Daily Rainfall Distribution Tails. Hydrology and Earth System Sciences, 17, 851-862. https://doi.org/10.5194/hess-17-851-2013

Pether, R. (2010). Design and Construction of Improvement Works at Bruton Flood Storage Reservoir, Somerset. Dams and Reservoirs, 20, 33-38.

https://doi.org/10.1680/dare.2010.20.1.33

Rakhecha, P. R., \& Clark, C. (1999). Revised Estimates of One-Day Probable Maximum Precipitation (PMP) for India. Meteorological Applications, 6, 343-350. https://doi.org/10.1017/S1350482799001280

Rodda, J. C. (1970). Rainfall Excesses in the United Kingdom. Transactions of the Institute of British Geographers, 49, 49-59. https://doi.org/10.2307/621640

Sebastianelli, S., Russ, F., Napolitano, F., \& Baldini, L. (2013). On Precipitation Measurements Collected by a Weather Radar and a Rain Gauge Network. Natural Hazards and Earth System Sciences, 13, 605-623. https://doi.org/10.5194/nhess-13-605-2013

Shaw, E. M. (1994). Hydrology in Practice (3rd ed., 613 p). London: Chapman \& Hall.

Singh, V. P. (2017). Handbook of Applied Hydrology. New York: McGraw Hill.

Stewart, E. J., Jones, D. A., Svensson, C., Morris, D. G., Dempsey, P., Dent, J. E., Collier, C. G., \& Anderson, C. W. (2013). Reservoir Safety-Long Return Period Rainfall. R\&D Technical Report WS 194/2/39/TR.

Strangeways, I. (2007). Precipitation Theory, Measurement and Distribution (290 p.). Cambridge: Cambridge University Press.

Sun, Q., Miao, C., Duan, Q., Ashouri, H., Sorooshian, S., \& Hsu, K.-L. (2018). A Review of Global Precipitation Data Sets: Data Sources, Estimation, and Intercomparison. Reviews of Geophysics, 56, 79-107. https://doi.org/10.1002/2017RG000574

World Meteorological Organisation WMO (2009). Manual on Estimation of Probable Maximum Precipitation (PMP) (259 p). WMO No. 1045, Geneva.

Wright, D. B., Smith, J. A., \& Baek, M. L. (2014). Flood Frequency Analysis Using Radar Rainfall Fields and Stochastic Storm Transposition. Water Resources Research, 50, 1592-1615. https://doi.org/10.1002/2013WR014224 